\title{
MOTIF PEREMPUAN BERKENDARA SEPEDA MOTOR TANPA HELM: STUDI KASUS DI KOTA SIDOARJO, JAWA TIMUR
}

\section{Motifs of Women Riding a Motorcycle Without a Helmet: Case Study in Sidoarjo City, East Java}

\author{
Irfan Rifai \\ Universitas PGRI Adi Buana Surabaya \\ Kampus II. Jalan Dukuh Menanggal XII \\ Surabaya, Jawa Timur \\ irfan.rifai@unipasby.ac.id
}

\author{
Fajar Susanto \\ Universitas PGRI Adi Buana Surabaya \\ Kampus II. Jalan Dukuh Menanggal XII \\ Surabaya, Jawa Timur \\ fajarsusanto@unipasby.ac.id
}

\begin{abstract}
This case study is aimed at revealing motives of women riding motor bike without helmet in Sidoarjo, East Java. The data in this study are garnered through interviews, focus group discussions, observation, and artefact including online newspapers, whilst thematic analysis is utilised as a primary data analysis. The findings of the study indicate that; first, distance from home to school is a most salient motive of women riding bike without helmet. Second, the absence of policeman on the street is a key factor of not wearing helmet. Third, social identity is another reason for not wearing helmet. Fourth, styles and its influence of feeling discomfort of wearing helmet. Fifth, social rules and its impracticality of not wearing helmet. The findings of this study are expected to have contributions of the ways to educate people about safety riding by involving students, students' parents, teachers and or stakeholders. This study, however, cannot represent all women perspectives of not wearing helmet when riding motor bike within Indonesia. Further research, therefore, is expected to consider areas and characteristics which might differ from the present study.
\end{abstract}

Keywords: women, riding motorbike without helmet, and case study.

\begin{abstract}
Abstrak
Penelitian ini bertujuan untuk mengungkap motif perempuan pengendara sepeda motor tanpa helm di daerah Kabupaten Sidoarjo, Jawa Timur, dengan menggunakan metode wawancara, Focus Group Discussion, observasi, dan analisis terhadap tulisan-tulisan yang ada di media sosial, seperti koran online. Analisis yang dilakukan menggunakan metode analisis tematik. Dari hasil analisis data diperoleh 5 tema yang menjadi pembahasan pada penelitian ini, yaitu: pertama, Jarak dari rumah ke sekolah menjadi pertimbangan utama responden tidak memakai helm; kedua, Kehadiran aparat kepolisian dan motif tidak memakai helm; ketiga, Identitas sosial sebagai alasan tidak memakai helm; keempat, style dan pengaruh ketidaknyamanan memakai helm; dan ke lima, aturan sosial dan ketidakpraktisan memakai helm. Hasil penelitian ini diharapkan bisa memberikan kontribusi informasi terhadap upaya mengedukasi masyarakat dalam keselamatan berkendara sepeda motor dengan melibatkan peran serta siswa, orang tua siswa, guru dan pemangku kepentingan. Namun demikian, dikarenakan penelitian ini terbatas pada studi kasus di Kota Sidoarjo, terdapat kemungkinan bahwa hasil yang diperoleh tidak dapat merepresentasikan perspektif perempuan pengendara sepeda motor di kota-kota lain di Indonesia. Untuk itu, penelitian ini diharapkan dapat dilanjutkan untuk kota-kota yang mempunya karakteristik berbeda dengan lokasi penelitian ini.
\end{abstract}

Kata kunci: wanita pengendara sepeda motor, helm, tidak pakai helm, keselamatan berkendara.

\section{LATAR BELAKANG}

Banyak penelitian tentang keselamatan jalan, baik yang melalui penelitian lapangan maupun penelitian yang bersifat eksperimen tentang keselamatan jalan, termasuk 
keselamatan berkendara sepeda motor. Penelitian yang dilakukan Sugiyanto \& Yumei Santi (2015) di Kabupaten Purbalingga Jawa Tengah, misalnya, melaporkan bahwa sepeda motor merupakan jenis kendaraan yang mendominasi kecelakaan lalu lintas dibanding dengan jenis kendaraan lainnya. Senada dengan penelitian Sugiyanto \& Yumei Santi, menurut data yang terekam di Direktorat Lalu Lintas, Kepolisian Daerah Jawa Timur, jumlah kecelakaan kendaraan sepeda motor menempati urutan tertinggi di antara kasus kecelakaan kendaraan motor lainnya, yaitu sekitar 32.745 kasus di tahun 2017 dan 12.046 di periode Januari-Oktober tahun 2018. Kota Sidoarjo adalah kota yang paling banyak memiliki kasus terjadinya kecelakaan kendaraan roda dua, yaitu sekitar 1.884 kasus di tahun 2017 dan 789 kasus di tahun 2018. Menurut penelitian, diperkirakan salah satu faktor penyebab kecelakaan pengendara sepeda motor di Indonesia adalah karena minimnya pengetahuan berkendara sepeda motor. Minimnya pengetahuan berkendara ini berpengaruh terhadap perilaku pengendara sepeda motor tersebut (Wesli, 2015). Selanjutnya, penelitian yang dilakukan oleh Wulandari, Jayanti, \& Widjasena (2017) menunjukkan bahwa tidak terdapat hubungan yang kuat antara masa berkendara dengan perilaku safety riding. Dari beberapa penelitian ini bisa dikatakan bahwa keselamatan berkendara sepeda motor dipengaruhi oleh berbagai faktor.

Walaupun penelitian tentang keselamatan jalan bagi pengendara sepeda motor banyak dilakukan dan usaha untuk menekan jumlah korban telah dilakukan secara intensif, misalnya melalui kampanye keselamatan berkendara, namun hasil penelitian menunjukkan tidak adanya cukup dampak yang sangat kuat terhadap kedisiplinan berkendara (Soviana \& Yuwono, 2010). Oleh sebab itu, penelitian yang fokus pada tingkah laku pengendara sepeda motor, khususnya perempuan, perlu dilakukan sebagai upaya untuk mengurai kompleksitas permasalahan berkendara sepeda motor.

Terdapat beberapa alasan mengapa kajian ini difokuskan kepada pengendara perempuan. Di antaranya adalah seperti yang diberitakan banyak media online bahwa praktik berkendara sepeda motor tanpa helm di kalangan perempuan menjadi masalah yang serius bagi aparat kepolisian. Selain itu, tingkah laku ibu-ibu dalam berkendara sepeda motor sering menjadi pemberitaan, seperti diilustrasikan di salah satu media online, yaitu menggigit tangan petugas kepolisian ketika hendak ditilang karena tidak memakai helm dan tidak membawa STNK. Selain itu, penelitian yang dilakukan oleh Haryanto (2016), mengungkapkan bahwa salah satu permasalahan yang berhubungan dengan keterampilan dan keselamatan berkendara sering dikaitkan dengan pengendara perempuan. Hal ini karena secara faktor sosial perempuan lebih sering diposisikan sebagai penumpang daripada pengendara.

Fenomena menarik praktik tidak memakai helm di kalangan ibu-ibu juga banyak ditemukan di kalangan ibu-ibu di kota Sidoarjo, terutama pada saat mereka mengantar anak ke sekolah dan menjemput anak di sekolah. Tren tidak memakai helm di kalangan ini perlu dikaji lebih dalam, untuk mengungkap motif ibu-ibu tersebut tidak memakai helm. Praktik-Praktik tidak memakai helm seperti ini, selain membahayakan diri sendiri, juga membahayakan anak yang dibonceng dan bisa sangat berpengaruh terhadap perkembangan kognitif dan tingkah laku anak dan orang lain di sekitar mereka. Albert Bandura (1977), dengan teori social learning, mengatakan bahwa "people learn from one another, via observation, imitation, and modeling”. Senada dengan social learning theory, Vygotsky (1978) mengatakan bahwa "social interaction plays a fundamental role in the development of cognition". Teori ini sangat jelas mengatakan bahwa orang mempunya kecenderungan untuk meniru dari orang lain melalui observasi, peniruan, dan modeling. Selain itu, 
pembentukan kognitif seseorang dipengaruhi oleh faktor interaksi sosial. Selain bahaya yang ditimbulkan oleh praktik mengendarai sepeda motor tersebut, tren berkendara sepeda motor dengan tidak memakai helm juga bertentangan dengan Undang-Undang Lalu Lintas dan Angkutas Jalan No. 22 tahun 2009, Pasal 57 ayat (1) jo ayat (2), dengan ancaman hukuman kurungan dan denda.

Menelaah motif ibu-ibu berkendara sepeda motor dan penumpang tanpa helm pada saat mengantar anak ke sekolah dan menjemput anak di sekolah melalui studi kasus sangat penting untuk dilakukan saat ini. Penelitian yang dilakukan oleh Rusti \& Falaah (2016), misalnya, menunjukkan bahwa faktor lingkungan, termasuk teman, berpengaruh terhadap sikap disiplin berkendara sepeda motor. Sedangkan menurut teori ecology, Bronfenbrenner (1999), mengatakan bahwa faktor lingkungan (ecology) sangat berpengaruh terhadap pertumbuhan kognitif dan tingkah laku manusia.

Tujuan penelitian ini adalah untuk mendalami motivasi ibu-ibu tidak memakai helm di Kota Sidoarjo pada saat mengantar dan menjemput anak mereka sekolah di sekitaran perumahan yang berada di Kota Sidoarjo, serta dampak tren ini terhadap pengetahuan dan sikap terhadap ibu-ibu lainnya. Selain itu akan dicari hal-hal yang melatarbelakangi kecenderungan tidak memakai helm dan faktor-faktor yang mempengaruhi mereka sehingga mengabaikan keselamatan diri sendiri dan anak. Beberapa pertanyaan yang diformulasikan dalam penelitian ini adalah motif atau faktor yang melatarbelakangi pengendara perempuan tidak memakai helm dan bagaimana faktor tersebut berpengaruh terhadap praktik-praktik berkendara tanpa helm.

\section{METODE PENELITIAN}

Penelitian ini didesain sebagai penelitian kualitatif atau study kasus, yang difokuskan pada motif ibu-ibu di Kota Sidoarjo mengendarai sepeda motor tanpa helm. Penelitian ini sangat relevan dengan karakteristik penelitian kualitatif, yang salah satu karakteristiknya adalah menganalisis pengalaman individu atau kelompok serta menganalisis everyday knowledge, accounts, and stories (Flick, 2007). Fokus utama penelitian ini adalah bagaimana memahami ibu-ibu mengendara sepeda motor dengan atau tanpa helm.

Responden penelitian ini adalah ibu-ibu yang biasanya mengantar jemput anak sekolah, baik yang tidak memakai helm maupun yang memakai helm. Ada 8 partisipan yang terlibat dalam wawancara dan 4 Focus Group Discussion (FGD). Sebelum dijadwalkan wawancara, responden diberi informasi secara rinci tentang tujuan penelitian, melalui Informed consent form atau ethical form). Pemberian ethical form ini dimaksudkan untuk meminimalkan munculnya power relations antara peneliti dengan partisipan. Selain itu juga dimaksudkan untuk menyatakan bahwa keterlibatan partisipan adalah sukarela. Jika mereka keberatan untuk melanjutkan wawancara, mereka bisa mengundurkan diri tanpa harus mengatakan alasannya. Setelah partisipan bersedia diwawancarai, tahap selanjutnya adalah menjadwalkan untuk wawancara. Sedangkan untuk FGD, pemilihan partisipannya menggunakan teknik snow ball, yaitu, salah satu partisipan diminta dan kemudian partisipan ini memilih sendiri anggota kelompoknya. Dengan menggunakan teknik ini, masing-masing partisipan akan dengan leluasa mengungkapkan ide atau pandangan terkait topik yang di bahas di FGD karena masing-masing partisipan sudah kenal satu sama lain. Alasan penggunaan FGD dalam penelitian ini adalah sebagai upaya melengkapi data yang didapat dari wawancara (Puchta \& Potter, 2004). Selain wawancara dan FGD, penelitian ini juga menggunakan observasi. Selama observasi, dilakukan pencatatan lapangan, 
pemotretan, dan perekaman kegiatan atau situasi subyek penelitian. Observasi ini digunakan sebagai upaya triangulasi data.

\section{Analisis Data}

Penelitian ini menggunakan analisis tematik. Menurut Braun \& Clarke (2006), ada beberapa tahapan dalam proses analisis tematik, yaitu familiarising oneself with the data, generating initial codes, searching for themes, reviewing themes, dan defining and naming themes. Sebagai upaya agar familiar dengan data, proses awal yang dilakukan adalah dengan mentranskripsi data hasil wawancara dan FGD. Setelah data ditranskripsikan, kemudian data diberi kode (coding). Dari hasil coding ini, data kemudian dikelompokkan berdasarkan tema-tema yang muncul, sehingga hasil akhir data wawancara adalah tematema yang akan dijadikan topik pembahasan. Sebagai triangulasi data, data yang diperoleh dari wawancara kemudian diperiksa kembali (cross check) dengan data yang diperoleh dari observasi, dokumen, dan data dari media, baik cetak maupun elektronik, sehingga data yang dihasilkan bisa lebih valid.

\section{HASIL DAN PEMBAHASAN}

Berdasarkan analisis data yang didapat dari wawancara, FGD, dan observasi, diperoleh tema-tema yang muncul dan kemudian tema-tema ini dijadikan hasil dan dibahas. Pembahasan tema-tema ini diurutkan berdasarkan tema yang sering muncul dari hasil wawancara dan FGD, yaitu: (1) Jarak dari rumah ke sekolah menjadi pertimbangan utama responden tidak memakai helm, (2) Kehadiran aparat kepolisian dan motif tidak memakai helm, (3) Identitas sosial sebagai alasan tidak memakai helm, (4) Style dan ketidaknyamanan memakai helm, dan (5) Aturan sosial dan kepraktisan.

\section{Jarak Menjadi Pertimbangan Utama Responden Tidak Memakai Helm}

Berdasarkan analisis data set, ditemukan bahwa jarak dari rumah ke tempat sekolah menjadi pertimbangan pengendara perempuan tidak memakai helm. Mayoritas responden mengatakan bahwa jarak antara rumah dan tempat sekolah tidak jauh, sehingga tidak diperlukan helm. Pengertian jarak tidak jauh menurut responden sangat bervariasi, yang meliputi dalam perumahan, antar perumahan, dan dalam wilayah kecamatan, seperti yang diilustrasikan seorang responden berikut:

"Masak mas, dekat saja pakai helm. Kan rumah saya dekat sekolah ini. ...ya kirakira 15 menit dari sini. Sampean (peneliti) tahu kan perumahan Citra Permata (anonim)? itu kan tidak jauh dari sini" (Responden 1).

Menurut responden tersebut, jarak tidak jauh bersinonim dengan waktu tempuh yang pendek. Namun demikian ada beberapa responden yang mengatakan bahwa jarak tidak jauh dimaksudkan sebagai jarak perumahan ke sekolah.

"Rumah saya dekat sekolah sini, mas. Ya..tetangga perumahan sini (sekolah). Tidak jauh kok. Jadi laopo (kenapa) pakai helm” (Responden 6).

"Sebenarnya saya harus pakai helm, mas. Tetapi kan dekat dari rumah (sekolah) ini. jadi saya pikir tidak masalah tidak pakai helm" (Responden 8).

Dari hasil penelitian ini dapat dikatakan bahwa, menurut responden, jarak dari rumah ke sekolah sangat berpengaruh terhadap praktik berkendara tanpa helm. Hasil penelitian ini 
mendukung penelitian sebelumnya yang mengatakan bahwa kecenderungan pengendara sepeda motor di jalan dipengaruhi oleh jarak (Rusti \& Falaah, 2016). Selain itu, sebenarnya hasil analisis juga secara eksplisit mengungkapkan bahwa selain jarak dari rumah ke sekolah, tipe jalan juga menjadi alasan bagi pengendara sepeda motor untuk tidak memakai helm. Analisis data memberi identifikasi bahwa jalan dalam perumahan atau jalan antara perumahan itu tidak termasuk jalan raya (jalan besar), sehingga pengendara tidak perlu memakai helm. Hal ini berhubungan sekali dengan kehadiran aparat kepolisian yang mengawasi.

\section{Kehadiran Aparat Kepolisian dan Efek Yang Ditimbulkan}

Analisis data menunjukkan bahwa faktor kehadiran aparat kepolisian sangat berpengaruh terhadap praktik keselamatan berkendara tanpa memakai helm. Responden masih menganggap bahwa jika tidak ada aparat kepolisian, berkendara tidak perlu memakai helm. Ketika seorang responded ditanya alasan tidak memakai helm, jawabannya adalah:

“...kan tidak ada polisi mas. baru kalau ada polisi saya pakai helm. tidak perlu lah kan cuma disini saja (di lingkungan perumahan). ...masak polisi akan menilang di jalan kampung” (Responden 3).

Dari jawaban tersebut dapat dinyatakan bahwa kesadaran diri sendiri untuk memakai helm, yang menjadi keharusan bagi semua pengendara sepeda motor, belum terbentuk dengan baik di kalangan ibu-ibu. Kesadaran memakai helm masih sangat dipengaruhi oleh faktor eksternal, yaitu petugas yang mengawasi. Hasil penelitian ini selaras dengan penelitian sebelumnya yang mengatakan bahwa alasan utama tidak mematuhi aturan rambu lalulintas di kota Yogyakarta adalah tidak adanya polisi yang mengawasi (Poei \& Ansusanto, 2016). Selain itu, dari hasil FGD juga diketahui bahwa kehadiran aparat kepolisian sangat berdampak kepada pengendara sepeda motor untuk memakai helm.
A: Iya, di jalan kampung seperti ini kan tidak ada polisi
B: kalau tidak ada pak polisi kan tidak ada razia, berarti tidak ada tilang
A: iya betul. masak di jalan kampung ada razia
C: ...tapi kalau saumpama ada polisi, kita juga pasti takut dan akan pakai helm (FGD 1).

Dari pernyataan responden dapat dikatakan bahwa kehadiran aparat kepolisian di jalan juga berarti kehadiran aparat untuk memberi peringatan bagi pengendara yang tidak memakai helm. Dengan kata lain, kehadiran aparat kepolisian berimplikasi kepada teguran, peringatan, sampai penindakan kepada pengendara sepeda motor yang tidak memakai helm, sehingga akibatnya pengendara sepeda motor mempunyai rasa takut jika tidak memakai helm di jalan, serta takut jika terkena tilang, berurusan dengan hukum, dan harus membayar sejumlah denda karena melanggar peraturan lalu lintas. Rasa takut yang ditimbulkan oleh pengendara sepeda motor ini lebih merujuk kepada faktor ekonomi dan hukum daripada faktor kehadiran aparat kepolisian itu sendiri.

\section{Identitas Sosial Sebagai Alasan Tidak Memakai Helm}

Selain efek langsung dan tidak langsung dari kehadiran aparat kepolisian, menurut analisis data ditemukan bahwa kecenderungan ibu-ibu tidak memakai helm karena ingin menunjukkan jati diri sebagai ibu-ibu yang modern, yaitu dengan menonjolkan pemakaian asesoris saat berkendara. Analisis dta menunjukkan bahwa adanya kecenderungan 
kesamaan di antara pengendara sepeda motor tanpa helm, yaitu kecenderungan memakai kaca mata hitam, penutup hidung dari kain panjang, dan kain penutup kepala warna hitam.

Iya betul, saya lihat juga begitu. Kebanyakan ibu-ibu sekarang kalau tidak pakai penutup hidung pasti memakai kacamata hitam. Kelihatannya ini jadi tren bagi ibuibu saat mengendarai sepeda motor. ...kacamata hitam dan bunder (bulat), ya mas.

...Kalau saya perhatikan, mereka memakai saat mengantar dan menjemput anaknya. jadi kaya ini gaya begitu, biar terlihat lebih modis (Responden 6).

Dari hasil wawancara dan FGD ditemukan bahwa praktik seperti itu berhubungan dengan style atau fashion. Responden menganggap bahwa dengan berpenampilan begitu, mereka akan terlihat lebih keren. Pernyataan ini didukung dari pengamatan di beberapa sekolah yang menunjukkan bahwa pemakaian kacamata hitam di antara pengendara ini dilakukan saat mengantar sekolah pagi hari dan penjemputan sekolah di siang hari. Dari analisis data diperoleh hasil bahwa memakai helm bagi ibu-ibu bisa menghalangi mereka untuk tampil modis. Alasan utamanya adalah wajah dan seluruh kepala tidak bisa terlihat seluruhnya sehingga kaca mata dan asesoris lainnya tidak bisa terlihat maksimal. Pesan inti yang disampaikan oleh ibu-ibu ini adalah bahwa helm bisa menghalangi untuk tampil modis.
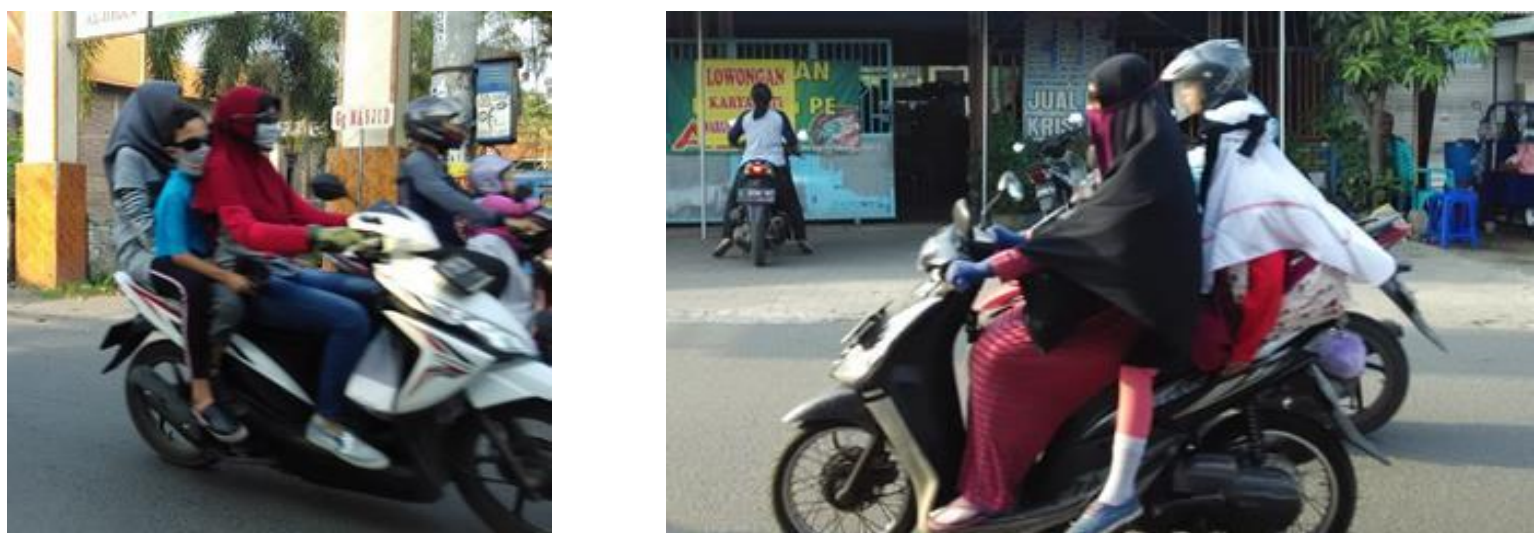

Gambar 1. Pemakaian kacamata hitam bulat dan penutup hidung.

Hasil penelitian ini sesuai dengan hasil pemikiran yang rilis oleh Pustral UGM,yang mengatakan bahwa penampilan menjadi salah satu alasan anak muda pengendara sepeda motor tidak memakai helm (http://pustral.ugm.ac.id/2016/05/04/mengapa-tidak-lagimemakai-helm/). Dengan kata lain, helm bisa berpotensi untuk menghalangi penampilan, dan semua yang menghalangi penampilan cenderung akan dijauhi. Namun demikian, hasil penelitian ini berbeda dengan penelitian sebelumnya. Salah satu faktor terbesar pengendara sepeda motor melanggar aturan lalu lintas di Yogyakarta adalah faktor tergesa-gesa (Poei \& Ansusanto, 2016), sedangkan pada penelitian tidak diperoleh data yang menunjukkan bahwa tidak memakai helm dikarenakan faktor waktu atau tergesa-gesa.

Selain itu, identitas sebagai bagian kelompok tertentu juga menjadi alasan ibu-ibu berpenampilan seperti yang dijelaskan sebelumnya.

A: Kami ini kan ibu-ibu satu sekolahan. Maksudnya, anak kami di sekolah yang sama

C: Jadi kami saling ngobrol sana sini, termasuk memakai kacamata hitam ini juga atas kesepakatan bersama

B: Iya betul. Kok saya lihat memakai kacamata hitam ini lebih terlihat bagus 
A: Juga kan bisa melindungi mata dari debu

D: iya betul. Jadi selain terlihat keren, juga melindungi

A: Manfaatnya dobel (FGD 2).

Hasil penelitian ini mendukung hasil penelitian sebelumnya yang mengatakan bahwa faktor terbesar ketiga pengendara melanggar lalu lintas adalah faktor 'ikut-ikutan' (Poei \& Ansusanto, 2016). Dalam penelitian ini 'ikut-ikutan' bisa dimaknai sebagai konsensus di dalam sebuah kelompok harus ditaati dan diikuti. Hasil penelitian ini memiliki kesamaan secara prinsip bahwa lingkungan yang permisif terhadap sikap pengendara motor yang tidak aman mempengaruhi perilaku seseorang untuk berkendara tidak aman juga (Muryatma, 2017). Di dalam penelitian Wulandari, Jayanti, \& Widjasena (2017) juga disebutkan bahwa peran atau pengaruh teman sejawat dalam berperilaku berkendara aman sangat terlihat.

\section{Style dan Ketidaknyamanan Memakai Helm}

Selain alasan fashion, memakai helm juga dianggap ibu-ibu sebagai hal yang tidak nyaman di kepala, kepala jadi berat, gerakan jadi kaku, hingga bisa mengakibatkan pusing.

"Kalau saya pakai helm itu, terasa berat. Kepala jadi pusing. Pokoknya tidak enak dan tidak nyaman, mas. Walau saya dipaksa, saya males kalau pakai helm. Daripada pusing (memakai helm) mending tidak usah saja. Toh, selama ini saya juga tidak apa-apa” (Responden 7).

Dengan beralasan tidak pernah terjadi musibah karena tidak memakai helm dan memakai helm dianggap sebagai sesuatu yang memberatkan bagi ibu-ibu, praktik tidak memakai helm ini akan banyak dijumpai di kalangan ibu-ibu. Selain faktor tersebut, memakai helm juga dianggap tidak praktis dan sangat mengganggu pergerakan saat berkendara. Memakai helm bagi ibu-ibu diartikan sebagai hal yang menghalangi dan membatasi untuk bergerak bebas. Salah seorang responden mengatakan:

“...kalau saya pakai helm, saya jadi bingung dan pandangan tidak luas. Memakai helm itu kayak gerakan jadi terbatasi. Pandangan jadi hanya di depan saja, susah kalau tengok kanan-kiri" (Responden 1)

\section{Aturan Sosial dan Ketidakpraktisan Memakai Helm}
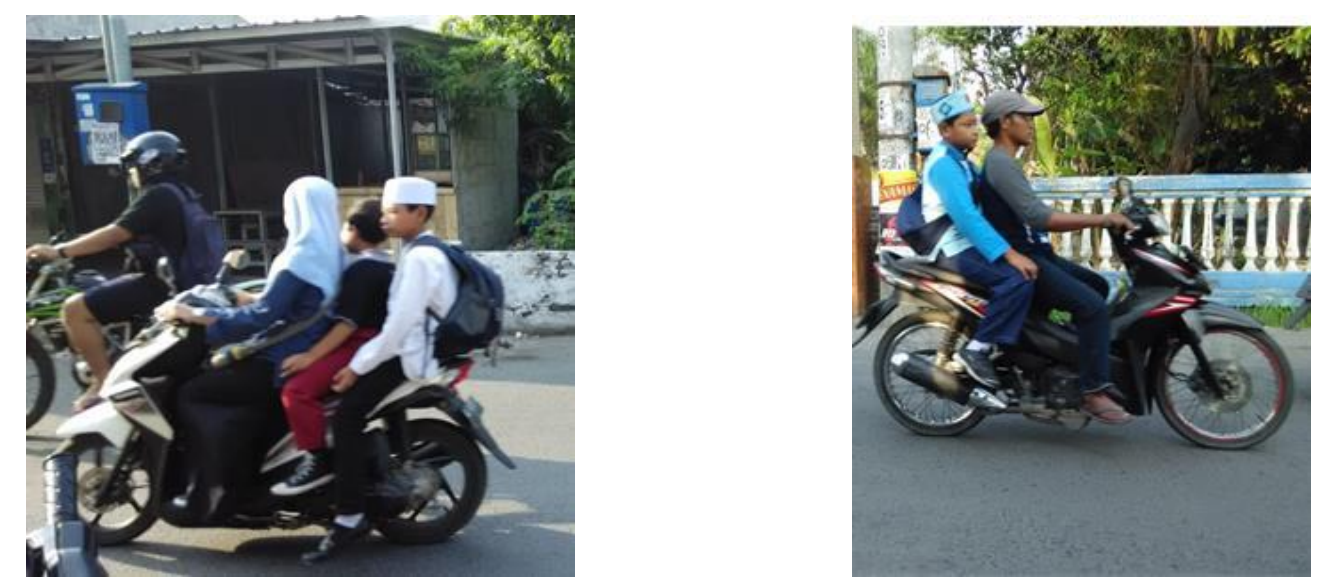

Gambar 2. Siswa memakai peci ke sekolah 
Tradisi sekolah juga berkontribusi terhadap banyaknya pengendara sepeda motor tanpa helm. Misalnya adalah tradisi sekolah yang mewajibkan siswa laki-laki untuk memakai kopyah saat di sekolah memberi dampak kepada siswa pada saat diantar ke sekolah untuk tidak memakai helm.

Alasan lain tidak memakai helm ke sekolah tetapi memakai peci dikarenakan alasan kepraktisan.

Repot jika memakai helm pas anak-anak harus pakai peci di sekolah. Pakai helm, kemudian pakai kopyah sesampai di sekolah. jadinya sedikit ribet mas. Mending sekalian dari rumah pakai kopyah saja biar di sekolah tidak usah dilepas-lepas. nanti kalau pakai helm jadi lupa kopyahnya. ini kan himbauan sekolah. (R4)

Dari hasil penelitian ini dapat disimpulkan bahwa memakai helm bisa merepotkan anak dan orang tua. Memakai kopyah adalah himbauan sekolah yang harus ditaati oleh semua siswa, sedangkan memakai helm tidak berdampak secara langsung, seperti bila mendapatkan teguran dari guru atau sekolah. Selain itu, efek yang bisa dirasakan langsung lebih mempunya dampak dibanding dengan efek yang belum terlihat dampaknya.

\section{KESIMPULAN DAN SARAN}

Dari analisis data set diketahui bahwa terdapat berbagai motif ibu-ibu mengendarai sepeda motor tanpa helm, mulai dari motif eksternal sampai motif internal. Motif eksternal bisa disebabkan karena pengaruh kehadiran aparat kepolisian, pengaruh sesama ibu-ibu, sampai pada pengaruh yang berupa peraturan sosial. Sedangkan pengaruh internal lebih karena kurangnya kesadaran diri terhadap keamanan dalam berkendara dan tidak menjadikan pemakaian helm sebagai kebiasaan dalam berkendara roda dua, serta motivasi untuk membangun identitas diri. Dengan kata lain, motif ibu-ibu tidak memakai helm dalam berkendara sepeda motor sangat kompleks dan upaya untuk meningkatkan kesadaran memakai helm bagi ibu-ibu juga tidak sederhana. Namun demikian, mendialogkan hasil penelitian dengan teori sosial dan kependidikan bisa membantu memberikan alternatif solusi permasalahan.

Sebagai contoh, dalam teori ecology ( (Bronfenbrenner, 1979), disebutkan bahwa terdapat 4 layer (lapisan) dalam memahami perkembangan anak, yaitu Microsytem, Exosystem, macrosystem, dan chronosystem. Dalam microsystem, anak berinteraksi dengan lingkungan terdekat, seperti keluarga, sekolah, dan tetangga. Dalam interaksi ini terjadi interaksi dua arah, baik dari anak ke lingkungan sekitar dan dari lingkungan sekitar ke anak. Berangkat dari teori ini, salah satu solusi masalah ibu-ibu tidak memakai helm saat berkendara bisa melalui peran edukasi anak dan peran sekolah. Faktor kepercayaan siswa terhadap guru dan sekolah yang tinggi mempunya kekuatan yang besar dalam meningkatkan kesadaran orang tua perihal berkendara sepeda motor yang aman. Peran sekolah atau guru melalui pengajaran, praktik, kunjungan ke institusi Polri maupun melalui himbauan atau instruksi ke siswa dan orang tua perihal keselamatan berkendara sepeda motor bisa sangat membantu untuk mengurai kompleksitas permasalahan keselamatan berkendara. Hal ini berarti bagaimana menjadikan siswa, guru, dan stake holders sebagai agen perubahan keselamatan berkendara. Dengan kata lain, hubungan yang sangat baik dan intensif antara sekolah, orang tua siswa, dan siswa menjadi hal yang positif untuk membangun kesadaran berperilaku berkendara sepeda motor yang baik, termasuk berkendara dengan memakai helm. 


\section{UCAPAN TERIMAKASIH}

Penulis mengucapkan terima kasih yang sebesar-besarnya kepada Direktorat Keamanan dan Keselamatan Korlantas Polri dan Traffic Accident Research Center atas bantuan hibah penelitian tahun anggaran 2018. Terima kasih juga penulis sampaikan kepada Bapak Ir. Tri Tjahjono, M.Sc., Ph.D. dan Bapak Andyka Kusuma, S.T, M.Sc., Ph.D. yang telah berkenan meluangkan waktu untuk menerima konsultasi selama penelitian. Penulis juga menyampaikan terima kasih kepada AKBP Ni Nyoman Suartini, S.I.K., M.MTr,; AKBP Aswin Azhar Siregar, SIK., M.Sc., Ph.D,; dan Kompol Adhitya Panji Anom, S.I.K. yang selalu memberi dukungan moral dan material dalam penyelesaian tulisan ini. Tidak lupa penulis menyampaikan terima kasih kepada orang tua siswa, guru, dan sekolah yang menjadi mitra peneliti yang telah membantu kelancaran penelitian ini, serta reviewer yang telah memberi masukan yang komprehensif untuk peningkatan kualitas tulisan ini.

\section{DAFTAR PUSTAKA}

Bandura, A. 1977. Social Learning Theory. New Jersey: Prentice Hall.

Braun, V., \& Clarke, V. 2006. Using Thematic Analysis in Psychology. Qualitative Research in Psychology, hal. 77-101.

Bronfenbrenner, U. 1979. The Ecology of Human Development. Cambridge: Harvard University Press.

Kepolisian Negara Republik Indonesia Daerah Jawa Timur Direktorat lalu Lintas. 2018. Data Laka Lantas.

Flick, U. 2007. Designing Qualitative Research. London: SAGE Publications.

Haryanto, H. C. 2016. Keselamatn Dalam Berkendara: Kajian Terkait dengan Usia dan Jenis Kelamin pada Pengendara. INQUIRY Jurnal Ilmiah Psikologi, hal. 92-106.

Muryatma, M. N. 2017. Hubungan antara Faktor Keselamatan Berkendara dengan Perilaku Keselamatan Berkendara. Jurnal Promkes, hal., 155-166.

Poei, E. P., \& Ansusanto, J. D. 2016. Perilaku Berlalu Lintas yang Mendukung Keselamatan di Jalan Raya. Jurnal Teknik Sipil, hal. 10-19.

Puchta, C., \& Potter, J. 2004. Focus Group Practice. London: SAGE Publications Ltd.

Rusti, S., \& Falaah, M. R. 2016. Praktik Safety Riding pada Pelajar di Wilayah Kerja Polres Padang Panjang. Jurnal Human Care, hal. 1-10.

Sugiyanto, G., \& Yumei Santi, M. 2015. Karakteristik Kecelakaan Lalu Lintas dan Pendidikan Keselamatan Berlalulintas Sejak Usia Dini: Studi Kasus di Kabupaten Purbalingga. Jurnal Ilmiah Semesta Teknika, hal. 65-75.

Soviana, E., \& Yuwono, S. 2010. Kampanye Keselamatan Berkendara: Pengaruhnya Terhadap Kedisiplinan dalam Berlalu Lintas. Indigenous, Jurnal Ilmiah berkala Psikologi, hal. 148-153.

Vygotsky, L. 1980. Mind in Society: Development of Higher Psychology Processes. Cambridge: Harvard University Pres.

Wesli. 2015. Pengaruh Pengetahuan Berkendara Terhadap Perilaku Pengendara Sepeda Motor Menggunakan Structural Equation Model (SEM). Teras Jurnal, hal, 43-50.

Wulandari, S., Jayanti, S., \& Widjasena, B. 2017. Faktor-Faktor yang Berhubungan dengan Perilaku berkendara Aman (Safety Riding) pada Kurir Pos Sepeda Motor di PT. Pos Indonesia Cabang Erlangga Semarang 2017. Jurnal Kesehatan Masyarakat, hal. 346355 .

Undang-Undang Lalu Lintas No. 22 tahun 2009. 
https://www.merdeka.com/peristiwa/polisi-sebut-ibu-ibu-banyak-yang-tak-disiplin-saatbawa-motor.html

https://www.merdeka.com/peristiwa/polisi-sebut-ibu-ibu-banyak-yang-tak-disiplin-saatbawa-motor.html

https://www.liputan6.com/otomotif/read/3310980/tak-pakai-helm-emak-emak-pukul-dangigit-polisi 